\title{
The search for the true self in the Gospel of Thomas, the Book of Thomas and the Hymn of the Pearl
}

\author{
Patrick J Hartin \\ Gonzaga University, Spokane
}

\begin{abstract}
At the heart of the Gospel of Thomas lies the call to achieve an understanding of one's self (Logia 67-70). This call focuses the struggle of Thomas Christians by turning it inward as a challenge to understand their own true identity Through this struggle they come to a knowledge of the Father. The significance of this theme of the search for the true self is examined further in the context of the Gospel of Thomas (Logia 3; 58; 111). From this study, it emerges that Thomas Christians experienced that they were strangers in a hostile world. Feeling alienated, they wished to escape from the world. The positive outcome of this experience was a deeper self-understanding. This study culminates in an examination of this theme of the search for one's self in two other writings at home within early Syrian Christianity. In the Hymn of the Pearl (Acts of Thomas 108113) the theme emerges in the allegory of the soul's quest for self-knowledge. The path to salvation is a search that ultimately takes one from the world. In the Book of Thomas the Contender the same search for one's identity is emphasised (138: 15-20 and 145:1-15). Finally, it is argued that this search for one's true identity is appropriate to the historical and sociological context of the Syrian Church in Edessa.
\end{abstract}

\section{INTRODUCTION}

The discovery of the Gospel of Thomas and the literature associated with his name have thrown new perspectives onto the development of Christianity in the first centuries of this era. This article will show how two themes (namely, the search for one's self, and one's alienation from the world) run throughout the Thomasine literature (namely, the Gospel 
of Thomas, the Book of Thomas and the Hymn of the Pearl) and reflect well the situation of Syrian Christianity in the first centuries of this era (Barnard 1968:161).

\section{A SEARCH FOR A KNOWLEDGE OF ONESELF IN THE GOSPEL OF THOMAS}

\subsection{Persecution and a knowledge of oneself (Logia 67-70)}

The theme of searching for an understanding of oneself emerges in the course of a number of sayings in the Gospel of Thomas that are connected with the theme of persecution (Logia 67-70). These sayings are situated at the heart of the Gospel. Logion 67 begins by stressing the importance of knowing oneself: "One who knows all, but is lacking in oneself, is utterly lacking." To be lacking in a knowledge of oneself means that one is deficient in the most essential thing of all.

Logia 68-69 continue this search for self-understanding. Logion 68, presented in the form of a beatitude, promises comfort to those who are hated and persecuted. The conditions for blessedness emerge as a consequence of the persecution that the Thomas Christians experience (Fieger 1991:197). The implication is that the world at large as well as the wider church are responsible for bringing hatred and persecution to bear on them (Fieger 1991:198). Ultimately, the promise is made that they will be protected from all persecution: "where you have been persecuted, they will find no place."

Logion 69 continues the theme of persecution: "Blessed are those who have been persecuted in their hearts: they are the ones who have truly come to know the Father ...." The focus now lies on the interior struggle with which they are engaged. This struggle shows the intensity of the persecution that the Thomas Christians experience. They are persecuted both from outside as well as from within. Without doubt, the world has the power to affect them and to persecute them. But, only through a process of separation from the world do the Thomas Christians come to know the Father. This is an appeal to the Thomas Christians to make a decision for the Father against the world. The second part of Logion 69b ('Blessed are they who are hungry, that the stomach of the one in ant may be filled') is to be read in a spiritual sense because of its context. The hungry are 
those Thomas Christians for whom the search for the Father is an all consuming desire and struggle. The hungry will ultimately be filled with a knowledge of the Father.

In effect, Logia 68-69 bear witness to a perspective where Thomas Christians experience themselves as besieged from every quarter. This experience has positive results because it leads to a deeper self-awareness. Starting with the experience of opposition that emanates from the world around them, they experience an interior struggle to discover themselves. They escape the world by concentrating upon themselves. The world may be able to harm their bodies, but the inner being is the place where they encounter the Father.

This series of sayings culminates in the call to the Thomas Christians to discover themselves through the decisions that they make every day in praxis (Haenchen 1961:49): "If you bring forth what is within you, what you have will save you. If you do not have that within you, what you do not have within you [will] kill you" (GTh 70). These decisions bring about a separation from the world. Whenever people realize that their home is not here in this world, they are ripe for the salvation that comes from the Father. The divine self within one is not an object, a thing, instead one experiences it in act (Haenchen 1961:61).

Separation from the world gives Thomas Christians the understanding of their acceptance by the Father: "they are the ones who have truly come to know the Father" (Logion 69). Their struggles in the world have led to the discovery of who they are their special relationship and status with God as Father. By centering upon themselves and their own interior struggles, they discover themselves and their true nature. The impulses for a correct understanding of oneself, an understanding that sets one off from the rest of humanity, have been energised by their experiences. In the act of rejection, Thomas Christians discover a new identity in relationship to God the Father. They are the ones who possess a special understanding and enlightenment that gives them strength to endure and withstand opposition and persecution.

\subsection{The search for one's true self: The heart of the Gospel of Thomas}

Logia 67-70 express what is at the heart of the outlook of the Gospel of Thomas. A close reading of the Gospel of Thomas shows how central the search for a true understanding 
of oneself is for the thought of the Gospel. Opening with a focus upon the search for one's true self, Logion 2 presents life as an endless, ongoing quest or search: "Let one who seeks not stop seeking until one finds. When one finds, one will be disturbed. When one is disturbed, one will marvel, and will reign over all." The following saying specifies exactly what this search is about: it is a search for self-understanding. "If your leaders say to you: "Behold, the kingdom is in heaven," then the birds of heaven will precede you. If they say to you, "It is in the sea," then the fish will precede you. Rather, the kingdom is within you and it is outside you. When you know yourselves, then you will be known and you will understand that you are children of the living Father" (Logion 3). The same connection was made by Logion 69a: Knowledge of self leads to a knowledge that you are children of the Father. The kingdom is that reality that proclaims one's relationship with the Father as well as the relationship that others also hold with the Father. It is a present reality both inside and outside oneself. This is what separates Thomas from other understandings of the kingdom within Christianity. In place of the inbreaking of the end of time into the world, Thomas sees the kingdom as a present reality that is discoverable within each person. The saying "When you know yourselves, then you will be known" (Logion 3:3) is similar to the saying of Paul in Gal 4:9: "Now, however, that you have come to know God, or rather to be known by God, how can you turn back again to the weak and beggarly elemental spirits?" However, there is a difference in emphasis. In Paul, it is a question of coming to know God in the future eschatological age. In the Gospel of Thomas, it is a matter of coming to know oneself in the present.

The path to the discovery of one's true self occurs through opposition to the world. Through a specific approach and attitude to the world one comes to a knowledge of oneself. While the Gospel of Thomas does use the term kosmos positively as that which is created by God (GTh 12;89), or as the place where the activity of Jesus and the Thomas Christians unfolds, it is rather in the negative connotation as a threatening and hostile force that I am interested (Hartin 1997:7-8). In the Gospel of Thomas, the world is portrayed as a threat that the Thomas Christians must be aware of and from which they must protect themselves. At the end of the Gospel, in Logion 111, the opposition between the world and finding oneself is starkly drawn: "Does not Jesus say, 'Whoever 
has found oneself, of that person the world is not worthy?" This phrase "of that person the world is not worthy" occurs on three occasions (GTh 56, 80 and 111) and is a way in which the Gospel of Thomas draws the sharp distinction between the world and the Thomas Christian. In the process of distancing oneself from and mistrusting the world, one finds oneself.

The interpretation of the parable in Logion 21 further shows this dangerous nature of the world against which the Thomas Christians must protect themselves. "As for you, then, be on guard against the world. Gird yourselves with great strength, lest the robbers find a way to get to you, for the trouble you expect will come. Let there be among you a person who understands." The most important possession of the house owner in the parable is going to be taken away by force. In a metaphorical way the world (the robber) is trying to take away from the Thomas Christian (the householder) what is the most prized possession, the kingdom that is within.

For Thomas, the world becomes more than the stage where I act. In conflict with the world, I discover myself. As Logion 58 says: "Blessed is the person who has suffered. He has found life." Patterson (Kloppenborg 1990:143) translates the verb used here (hise) as "toil" instead of "suffer." While this verb can have the meaning of "to labour, to toil, to suffer," from the context as well as from its usage elsewhere, I think that the understanding of "to suffer" seems to conform more to the meaning here. This suffering originating from the world must have touched them in the very depths of their being. This opposition makes them realize that they do not belong to the world, but that they are aliens in a hostile world.

For the Thomas Christians to know the kingdom of God is to know one's true identity as "children of the living Father" (GTh 3). The coming of the kingdom is ultimately an event that occurs as the disciples come to understand themselves and realize that the Father dwells in them: "Whoever is near me is near the fire, and whoever is far from me is far from the kingdom" (GTh 82). This implies that human beings are radically grounded in God. This brings about a differentiation from every other bond and every relationship in the world. This core of one's being, this "self", is not an object in the world and so is not limited to the lifespan of a person: it transcends the life of a person in this world: "Jesus said, If they say to you, 'Where have you come from?' say to 
them, 'We have come from the light, from the place where the light came into being by itself, established [itself], and appeared in their image.' If they say to you, Is it you? say, 'We are its children, and we are the chosen of the living Father'. If they ask you, What is the evidence of your Father in you? say to them, 'It is motion and rest"'(GTh 50). The task of life is to come to understand oneself. Knowledge of the divine self within one is realized in the course of daily life. It is not something that is awaited for the future, but is realizable in the present.

One comes to know oneself through a radical separation from the world. As Logion 42 says: "Be passersby" (GTh 42). In graphic description, the Gospel of Thomas compares the world to a carcass (GTh 56). Here Thomas shows the distinction between the self and the world - the self is a living being, while the world is a dead thing. To place one's trust in the world is a futile exercise - it is misplaced trust in something already dead.

Thomas uses an graphic metaphor to capture this call to separate oneself from the world: "If you do not fast from the world, you will not find the kingdom" (GTh 27). Fasting from the world is in essence the adoption of a rigorous, ascetical way of life (Gärtner 1961:239). This separation from the world is achieved in a number of diverse ways. It is achieved first of all through the breaking of personal bonds with the world. The radical nature of the Gospel of Thomas in this connection is very clear. Not only is it intent on abolishing all distinctions between male and female, it also attacks all distinctions by which one finds that one is bound to the world. I agree with Haenchen (1973:214-215) in interpreting Logion 37 as presenting an ideal of returning to the original state of unity in paradise: "His disciples said, 'When will you appear to us, and when shall we see you?' Jesus said, 'When you strip without being ashamed, and you take your clothes and put them under your feet like little children and trample them, then [you] will see the son of the living one and will not be afraid." In the reversal to the state of paradise, one returns to a situation where the separation of the sexes is no longer a conscious reality. Renunciation of relationships also entails the renunciation of bonds within the family (GTh 16;55 \& 101). The consequent suffering and persecution is provoked by one member of the family becoming a follower of Jesus. 
Through separation from all worldly connections, Thomas Christians become monachoi. The meaning of this term monachos has been examined in numerous studies over the past few decades (Adam 1953/4:203-239). The interpretation that refers to those who have separated from the world and that "stand alone" seems to make the most sense. This is seen from Logion 16: "Perhaps people think that I have come to cast peace upon the world. They do not know that I have come to cast conflicts upon the earth: fire, sword, war. For there will be five in a house: there will be three against two and two against three, father against son and son against father, and they will stand alone (monachos)." The one who has renounced the bonds of the world will enter the kingdom: "There are many around the drinking trough, but there is nothing in the well ... There are many standing at the door, but those who are alone (monachos) will enter the wedding chamber" (GTh 74 and 75). They have broken away from their family bonds and ties; they stand alone and become members of the Thomas group. In them the kingdom becomes a reality. It is in this way that they discover themselves as "children of the living Father" (GTh 3). A further way of separation from the world occurs through the renunciation of wealth. For example: "Let one who has found the world, and has become wealthy, renounce the world" (GTh 110). Further, Thomas concludes the parable on the invited guests with the saying: "Buyers and merchants [will] not enter the places of my Father" (GTh 64).

In this search for one's self and in the opposition that is encountered from the world it is clear that the sayings in the Gospel of Thomas are more than just wisdom sayings. The incipit of the book has identified itself as: "These are the secret sayings that the living Jesus spoke and Didymos Judas Thomas recorded" (GTh 1). While many of the sayings in the Gospel of Thomas bear evidence of being both ancient and traditional, the way they have been handed on shows they have undergone reflection and appropriation within a new cultural perspective and framework. The quest for a knowledge of oneself, which lies at the heart of the final form of this Gospel, is one that also lies at the heart of the Gnostic search for knowledge. However, the theological framework of the Gnostic mythology of a descending and ascending redeemer is totally absent from the Gospel of Thomas. The final form of this Gospel is not representative of a fully fledged Gnosticism, but perhaps of an intermediary stage in the development of the religious 
thought world that lies somewhere between the Jewish wisdom traditions and a later fully developed Gnosticism as found in the gnostic dialogues. Thomas is stamped by what Patterson (1993:227) has called "an esotericizing trend" whereby sayings from the traditions that Thomas has inherited have been understood as containing special knowledge for those who belong to the community of the Thomas Christians.

\section{THE SEARCH FOR A KNOWLEDGE OF ONESELF IN OTHER THOMASINE TRADITIONS FROM EARLY SYRIAN CHRISTIANITY, NAMELY THE BOOK OF THOMAS AND THE HYMN OF THE PEARL}

This quest for an understanding of oneself through alienation from the world is continued in other writings that are identified as belonging to the Thomasine tradition and are seen to emerge from within early Syrian Christianity. Turner (1975:233-234) identifies the development of the Thomas tradition as though it were situated along a line with three important points witnessing its development, namely the Gospel of Thomas, the Book of Thomas, and the Acts of Thomas. All three works are unified by their focus upon the search for oneself together with an ascetic approach to the world (Turner 1975:233-234).

The very nature or genre of each writing supports the middle position attributed to the Book of Thomas. The Gospel of Thomas consists largely in a long list of sayings of the living Jesus, sayings that have been expanded briefly over time with an interpretation that has an esoteric and gnosticizing tendency. In the Book of Thomas the development and expansion has been more extensive with the result that the interpretation has almost totally supplanted the original saying. Ultimately a new genre emerges, namely that of the dialogue whereby the Risen Savior teaches his disciples directly by means of a dialogue with his disciples. This development is the basis for Turner's argument (1975:136) that the Book of Thomas comprises a twofold development. First of all, Section B (142: 27-143:23) was a development of sayings much in line with those of the Gospel of Thomas, though the interpretative element dominated more strongly. Later these sayings were prefixed by means of an independent development of a dialogue between the Savior and his disciple, Thomas (identified as Section A [138:4-142:26]). Hence, a new genre 
emerges, namely that of the dialogue (Tumer 1975:108-109). This gives the sayings a new character and a new lease on life.

The Acts of Thomas demonstrate an even later stage in this development. In the Gospel of Thomas Jesus was the spokesperson for his sayings and Thomas appears only in one episode (namely, GTh 13). In the Book of Thomas a more central role is given to Thomas who enters into dialogue with the Savior (who is no longer the sole spokesperson). Now, with the Acts of Thomas, Thomas becomes the main character. The genre is not that of a Sayings Gospel (as the Gospel of Thomas), or of a Dialogue with the Savior (as The Book of Thomas). Instead, it is a narrative that presents a story about the life and missionary activity of the bearer of these traditions, namely Thomas. As Turner (1975:234) says: "On the other hand, in the Acts of Thomas, Thomas is always and everywhere the central character: apostle to India, recipient of secret words, proclaimer and counselor of abstinence from what is carnal, and, finally, martyr."

\subsection{The Book of Thomas the Contender}

The Book of Thomas demonstrates a close theological connection with the Gospel of Thomas. While certain themes and perspectives are common to each, the Book of Thomas develops these perspectives further by showing a later development of the Thomas traditions within the context of Syrian Christianity. The main thrust of the Book of Thomas is a call to know oneself, to come to an understanding of oneself, which like the Gospel of Thomas involves an escape from the world as represented in the body, the seat of all desires and lusts.

The theological character of the Book of Thomas demonstrates a dualism with regard to the human being and the world. However, this dualism is not well developed in the Book of Thomas. Just as the Gospel of Thomas did not enter into speculation on the origin of the world, et cetera, so too the Book of Thomas did not develop Gnostic speculation into an organised system that controls the entire theology even though it is certainly more evident than in the Gospel of Thomas. For example,

I tell you that he will be handed over to the Archon who is above, he who rules over all the powers as their king, and he will turn that one around and 
cast him from heaven down to the abyss, and he will be imprisoned in a narrow dark place. Moreover, he can neither turn nor move on account of the great depth of Tartaros and the [wide wall] of Hades that is set [against him. They are] [imprisoned] in it in [order that they might not] [escape] (142:3038).

The Book of Thomas opens in a way analogous to the Gospel of Thomas. Turner (1975:136) draws attention to five topics that are considered in both the Gospel of Thomas and the Book of Thomas in an analogous way:

$\begin{array}{llll} & & \text { Gospel of Thomas } & \text { Book of Thomas } \\ 1 & \text { Secret word spoken to Judas Thomas } & \text { Introduction } & 138: 1 \mathrm{f} \\ 2 & \text { Seek and inquire } & \text { Logion } 2 & 138: 8,(22 \mathrm{ff}) \\ 3 & \text { Know thy self } & \text { Logion 3b } & 138: 8-10 \\ 4 & \text { Hidden and revealed } & \text { Logion 5,6b } & 138: 19-33 \\ 5 & \text { Beast and eating } & \text { Logion } 7 & 138: 39-139.11\end{array}$

Both works open with a similar subject matter, pointing to the Book of Thomas's knowledge of the Gospel of Thomas (Turner 1975:136). This supports the perspective that both works belong to a similar stream of tradition. Of significance in the above outline is the importance given to the call to "know thyself." This was a central thought in the Gospel of Thomas, identified at the beginning and carried on throughout the rest of the work. A similar importance is attributed to the discovery of one's self in the Book of Thomas: "Since it has been said that you are my twin and my true companion, inquire that you may understand who you are, and in what you exist, or in what manner you will come to be" (138:8-10). While these words are addressed to Thomas, they are meant as a call to all Thomas Christians to "know themselves". As Jesus says a few verses later: "For he who has not known himself has known nothing, but he who has known himself has also already obtained knowledge about the depth of the All" (138:16-18).

The knowledge of oneself is not a knowledge about Gnostic systems that explain one's origin and that of the world. Rather, it is a knowledge that concentrates upon the present and one's future destiny. Both are inextricably bound together. Knowledge of 
oneself in the present enables one to know how to act and this influences what will happen in the future. Knowledge of oneself brings with it the understanding that one must take seriously the duality between the material and spiritual worlds. Salvation consists for the human in escaping from the material, from the body and from the world. If one is too closely connected to the body and to the world, one will continue to be associated with them at death. The result is that one will perish, because the future of the material is its ultimate destruction. "So just as the body of the beasts perishes, so also will these bodies perish" (139:6-7).

The Book of Thomas offers a secret knowledge that brings an awareness of the power of the body and of the world to deceive the human being's spirit. This deception derives from strong impulses, such as the sex drive, that entrap one in the bodily world. The Book of Thomas calls on Thomas Christians to deny the body and be identified with those elect who have abandoned bestiality: “... whenever all the elect abandon bestiality, then this light will withdraw up to its essence, and its essence will welcome it, since it is a good servant" (139:28-31). All forms of sexual intimacy must be denied. For example, "Woe to you who love intimacy with womankind and polluted intercourse with it. And woe to you because of the powers of your body, for those will afflict you" (144:8-12). While the Gospel of Thomas gave emphasis to an ascetical way of life by avoiding family ties and all bonds to the world, the Book of Thomas has gone further by singling out sexuality as the area of most concern and one to be avoided at all costs. In line with its cultural heritage and background, the Book of Thomas uses the image of fire as a symbol for sexual passion. It is the fire of lust that enslaves human beings who are entrapped in the same vicious circle of sexual procreation wherein they were given life. "Does it (the body) not derive from intercourse like that (body) of the beasts? If it too derives from it (intercourse), how will it (the body) beget anything different from them (beasts)?" (139: 8-10).

One must in effect disown one's body: "Do you possess that which is visible (that is, a body)?" asks the Savior in 142:6. The Savior goes on to answer the question by illustrating the fate of the body where it will be consigned to the punishment of hell (142:10-18). Thomas is told that he may by accident have a body, but unless he is willing 
to disown the body he is going to share in its fate of damnation. In this way the Savior reveals one's true identity and destiny.

The call to understand one's situation and to avoid the lure of the body and the world is made even more urgent in a series of twelve woes that are presented in 143:8$144: 21$. Once again the command to avoid sexual intimacy is central: "Woe to you who love intimacy with womankind and polluted intercourse with it! And woe to you because of the powers of your body, for those will afflict you" (144:8-12).

The final promise with which the Book of Thomas concludes brings together the whole direction of the instructions. "For when you come forth from the sufferings and passions of the body, you will receive rest from the Good One, and you will reign with the King, you joined with him and he with you, from now on, forever and ever. Amen" (145:12-16). The final escape from the body will bring with it escape from sufferings and rest wherein you will be united with the Good One. Salvation is both rest from the body and eternal rest with God. The Book of Thomas opened with a call to know yourself. It ended with the discovery of one's true self which is to be found in the separation from the body and in union with God. To receive and to carry out the teaching given by the Savior will enable one to come to know oneself.

The Book of Thomas has appended to it a subscript title that claims that it is Thomas the Contender who is writing this to the perfect ones (145:1خ-19). The very title

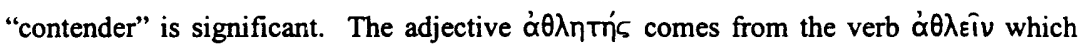
indicates "to compete in a contest" (Amt 1957:20). In the context of the Septuagint and the New Testament, it takes on the connotation of striving until death, as in the case of martyrs. For example, 1 Clement 5:1 where the apostles are referred to as "contestants

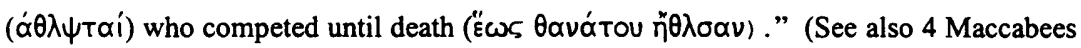
17:11-16:

Truly divine was the contest in which they were engaged. On that day virtue was the umpire and the test to which they were put was one of endurance. The prize for victory was incorruption in long-lasting life. The first to enter the contest was Eleazar, but the mother of the seven sons competed also, and the brothers as well took part. The tyrant was the adversary and the world and the life of men were the spectators. Piety won the victory and crowned her 
own contestants. Who did not marvel at the champions of the divine Law; who were not amazed?

(Charlesworth 1985:562-563)

Thomas is one who has engaged in a contest, a struggle, where he contended against the passions of the body and his fellow Christians are urged to shun the enticement of the body and adopt sexual abstinence.

Thomas addresses his message "to the perfect" ( $\left.T \sum_{\lambda_{\varepsilon}} O \mathrm{O}\right)$ in the sense that they are called to be perfect. They are called to shun all passions, to deny the body and to lead their lives accordingly. They are called to adopt an ascetic way of life. In effect, the Book of Thomas says to the readers: To be perfect, you must deny the body. This will free you from your sufferings and you will attain rest.

\subsection{Know yourself: The spirituality of the Gospel of Thomas and the Book of Thomas}

This examination of the Book of Thomas demonstrates how the thought world of both the Gospel of Thomas and the Book of Thomas converge. Central to both documents is the call: "Know yourself." Both writings open with this concern. For the Book of Thomas the concern is with the present and with the future, not with the past: "Inquire that you may understand who you are, and in what way you exist, and in what manner you will come to be" (138:8-10). The Gospel of Thomas focuses on the relationship with the Father who dwells within. "When you know yourselves, then you will be known, and you will understand that you are children of the living Father" (GTh 3). This will endure into the future as well. Both documents show that by receiving and carrying out the teaching of the Savior one ultimately gains an understanding of oneself.

Connected with the desire to discover and know oneself is the theme of suffering and persecution. Both documents give the assurance that one will triumph over the sufferings and persecutions that one endures for one's faith. Through suffering one discovers oneself.

The Book of Thomas belongs to the same theological trajectory as the Gospel of Thomas, being a development upon the thought of the Gospel. As with the Gospel of 
Thomas, the Book of Thomas can be classified as ascetic and dualistic. Through an ascetic escape from the world, and from the body, one grows in an understanding and awareness of one's self. The Gospel of Thomas is ascetic in its concem to escape from the world, from all the ties that bind one to the world, be it family, relationships or wealth. The asceticism of the Book of Thomas focuses on the passions of the body and calls for a denial of all sexual intimacy. By abandoning the lusts of the body in this life, one escapes the ultimate fate of the body.

However, the two writings show a difference in the emphasis given to this thought. The Gospel of Thomas addresses the concern to abstain ("to fast") from the world. There are only a relatively few places where this Gospel makes reference to the rejection of the sexual life, especially in its understanding of the rejection of the distinction between the sexes. Only four references are made to the rejection of the sexual life out of the following references to the rejection to the world $(22,27,37,42,48,68,69,78$, $79,81,110,114$; Turner 1975:235). On the other hand, the Book of Thomas places its emphasis much more directly and specifically on sexual abstinence: the sexual is what we share with all animals, and since it belongs to the body it is destined to be destroyed. This growing emphasis on sexual abstinence is part of the developmental tendency found in the Thomasine traditions of Syrian Christianity. The Book of Thomas in a sense lies midway between the Gospel of Thomas and the Acts of Thomas. This is further supported by the attitude of the Acts of Thomas where sexual abstinence is in the forefront of the narrative. Direct appeals are made in stories to lovers to abstain from sexual activity. Within these traditions, one observes a growing shift in thought from abstinence in a general sense to a narrower focus on sexual abstinence. This conforms to the spirituality of Syrian Christianity, as we know it, with its center in Edessa. As Turner (1975:136) says: "The great figures of Syrian Christianity (Tatian, Marcion, Mani) as well as its chief literary products under the name of Judas Thomas, strongly contend for such abstinence."

\subsection{Know yourself: The Hymn of the Pearl (Acts of Thomas 108-113)}

Finally, I turn to look briefly at "the Hymn of the Pearl," one of the more well known pieces of poetry from Syriac literature, as A F J Klijn (1960:154) terms it, in order to see how this search for an understanding of oneself continues. In its present form, the Hymn 
of the Pearl is part of the larger work, the Acts of Thomas. The manuscripts of the Acts of Thomas that we possess differ as regards what episodes et cetera they include. This seems to indicate that as the text of the Acts of Thomas was handed on it constantly changed and grew. There are only two manuscripts (a Greek one from the eleventh century, and a Syriac one from the tenth century) that contain the Hymn of the Pearl. These two manuscripts are the only existing evidence for the text (Layton 1987:370).

It seems that the Hymn of the Pearl was only later incorporated into the text of the Acts of Thomas (Layton 1987:369). Thus, it is very difficult to assign an exact date to this hymn. Scholars have adopted two approaches: If it were an early hymn (and one that might originally not even have been Christian), it could have provided the overarching framework for the development of the Thomas tradition, providing its "theological or philosophical" structure. If it were a document later than the other Thomasine writings, it then would be judged to present a summary (perhaps a popular one) of the Thomasine theological framework and model (Layton 1987:369). I prefer to see it in the latter sense, as a good summary of the developing Thomasine reflection on the search for a true understanding of oneself.

The hymn gives expression to a myth or fairy-tale (Klijn 1965:139-140) concerning humanity's salvation expressed allegorically (Layton 187:366). The text itself provides a clue to the allegorical interpretation in verses 76-78:

But suddenly, when I saw it (the robe) over against me,

The <splendid robe> became like me, as my reflection in a mirror;

I saw it <wholly > in me

And in it I saw myself < quite> apart < from myself>,

So that we were two in distinction

And again one is a single form."

The robe is a "mirror image," the true self, which the king's son only discovers on returning to the kingdom. This operates as an allegory for the quest of self-knowledge, and the ultimate discovery of one's true self. It is the account of the expulsion from and return to paradise. It describes how God's image is freely lost, but then ultimately recovered. Put in other words, it describes how the human being becomes mortal and then 
regains his immortality with God. As Klijn (1960:163) described it: "The back-ground of this hymn describes the adventures of the soul sent from its heavenly abode in order to gain the kingdom of God. It shows that after fulfilling its charge it receives its reward."

This basic theme fleshes out what lies at the background to both the Gospel of Thomas and the Book of Thomas. The call to know oneself gave direction and meaning to the content of both documents. "Inquire that you may understand who you are, and in what way you exist, and in what manner you will come to be" (Book of Thomas 138:810). The focus in the Gospel of Thomas is in one's relationship with the Father who dwells in one. "When you know yourselves, then you will be known, and you will understand that you are children of the living Father" (GTh 3). Now the Hymn of the Pearl shows that this discovery occurs in the kingdom of the Father when one reawakens from the sleep into which one falls in this world.

Connected with this theme of the quest for self-knowledge is another theme also important in the other two Thomasine documents, namely the struggle and the opposition experienced from the world. In the case of the Hymn of the Pearl, this opposition emerges in the entry into Egypt and the encounter with the Egyptians and the serpent, those forces preventing one within the world from accomplishing one's true destiny.

The Gospel of Thomas and the Book of Thomas counter the opposition of the world by abstaining from it. While the Gospel of Thomas focuses on abstinence in general from family, bonds, relationships and wealth, the Book of Thomas stresses this abstinence more in terms of sexual abstinence. For the Hymn of the Pearl, this abstinence expresses itself in the symbolic act of disrobing and awakening to the true knowledge of oneself:

And their dirty and unclean garment

I took off and left in their land

And directed my way that $<$ I might come $>$

To the light of our homeland, the East.

(verses 62-63) 
The result is reunion with one's true self and with God which brings peace and rest.

And my toga of brilliant colours

I drew < completely> over myself

I clothed myself with it and mounted up

To the gate of greeting and homage...

For he rejoiced over me and received me,

And I was with him in his kingdom

(verses 98-102)

As indicated above, the theological perspective is truly consonant with the other two Thomasine documents. A study of the geographical descriptions in the Hymn reveal a knowledge of the kingdom of Parthia. In addition, the Syriac version shows a language and vocabulary that makes use of Persian loan words. (Drijvers 1992:332). This all goes to support an origin for the Hymn in Eastern Syria, home to the Thomasine traditions, around the beginning of the third century. (Drijvers 1992:332). The Hymn of the Pearl spells out more fully the implied philosophical myth that seems to lie behind them all. The search for one's true self provides the impetus that drives all three documents. The Hymn of the Pearl has given a much more detailed and graphic description of this search and its culmination.

\section{CONCLUSION: THE CONTEXT OF THE CHURCH IN EDESSA}

As has been demonstrated, the human being's search for the true self through the right understanding of the teaching revealed by Jesus the Savior is a central theme running through this Thomasine literature. Salvation is not sought in the event of the Cross, but in Jesus' message of the unity of the self with the divine. The human being should, according to the Gospel of Thomas, become a "single one" which implies that all differences between male and female should disappear. For the Book of Thomas, sexual abstinence aimed as well at the return to one's original state by withdrawing from the bonds of the body. The Hymn of the Pearl showed this reunion in the most descriptive way of all. 
This distinctive body of literature is to be situated within a Syrian-speaking Chrisianity that has Edessa as its center in the second century CE (Drijvers 1982:171). In fact, Edessa turns out to be home to a number of traditions connected with the Apostle Thomas, considered to be Jesus' twin. It is of interest that the nun Egreria visited Edessa in 384 and she wrote in her travels: "I also wanted to make a pilgrimage to the martyrium of the holy apostle Thomas, where his entire body is buried. It is at Edessa, to which Jesus, our God, was sending Thomas after his ascension to heaven, as he tells us in the letter he sent to King Abgar by the messenger Ananias" (17,1; Wilkinson 1981:113). She also notes that when she visited Edessa she also read "from the writings of holy Thomas himself" $(19,2)$. This bears witness to the fact that the writings of which Thomas is the central figure are associated in the early tradition with the city of Edessa (Drijvers 1996: 172).

At the same time, the Thomasine literature reflects ideas at Edessa that other sources show were evident in this Christian community. Asceticism seems to have been a key characteristic of Christianity in Edessa, as is witnessed by Tatian (in Edessa around $172 \mathrm{C} \mathrm{E})$. His ascetical practices led him to reject marriage which he denounced as formication (Adv Haer 1.26). For Tatian, the only way to attain salvation and thereby to return to one's original immortality was through sexual asceticism (enkrateia; Drijvers 1994:129). Evidence from the Diatesseron points to Tatian correcting the tradition of the canonical Gospels in an ascetic direction. For example, in Luke 2:36 where the canonical text refers to the prophetess Anna, who "lived with her husband seven years after her marriage ...." Tatian, however, has Anna remain a virgin while she is married (Barnard 1968:168). The popularity of the Diatesseron in Edessa and Syrian speaking Christianity could be attributed to the ascetical direction that the translation took in that it reflected the spirituality of that church from the beginning (Barnard 1968:169).

It is probably best to envisage a large Christian presence in Edessa consisting of "a complex collection of loosely connected groups toward the end of the second century" as Klijn (1965:173) says. It would provide the matrix for distinctive groups to emerge such as those that centered around the traditions of Thomas. One particular challenge Christians faced in Edessa was to define their position vis-à-vis the large Jewish population in the city. Marcion, another prominent figure active in Edessa, who was anti- 
Jewish, forced Gentile Christians to examine their own relationship to Judaism. This provoked a strong desire to distance themselves from Marcion and to hold onto the Old Testament as part of the Bible. For this specific reason, the Peshitta emerged, a translation of the Old Testament that was different from the text used by the Jews. As Drijvers (1994:141) says: "All the available evidence points in the direction that Syriacspeaking Christianity in northern Mesopotamia and in the East Syrian region was mainly of Gentile origin and that some of these Christians were more attracted by Judaism than the Jews were drawn to Christianity." In the search for one's own self, it was necessary to distance oneself from these divergent and competing groups. This witnesses to a Christianity that was divided within itself as well as against those outside the group.

This theme of the search for one's identity is suitable to this historical and sociological context of the Church in Edessa. As many studies on this church at Edessa have shown, it was no monolithic community. The identity of the Gospel of Thomas and its related literature would be formulated by its alienation and separation from other groups. It is precisely from this opposition encountered in the interchange with other groups that the search for their own identity emerged.

\section{Works Consulted}

Adam, A 1953-54. Grundbegriffe des Mönchtums in sprachlicher Sicht. ZKG 65, 20939.

Arnt, W F \& Gingrich, F W 1957. $\dot{\alpha} \theta \lambda \dot{\varepsilon} \omega$, in A Greek-English Lexicon of the New Testament and other early Christian literature. Chicago: Chicago University Press.

Barnard, L W 1968. The origins and emergence of the church in Edessa during the first two centuries A.D. Vigiliae Christianae 22, 161-175.

Bondi, R C 1985. The spirituality of Syriac-speaking Christians, in McGinn, B \& Meyendorff, J (eds), Christian spirituality: Origins to the twelfth century. New York: Crossroad.

Charlesworth, J H 1985. The Old Testament Pseudepigrapha, vol 2. London: Darton, Longman \& Todd. 
Davies, S 1983. The Gospel of Thomas and christian wisdom. New York: Seabury.

Drijvers, H J W 1970. Edessa und das Jüdische Christentum. Vigiliae Christianae 24, 433.

- 1982. Facts and problems in early Syriac-Speaking Christianity. The Second Century, 2, 157-175.

- 1992. The Acts of Thomas, in Schneemelcher, W (ed), New Testament Apocrypha, vol 2, 322-411. Tr by R McL Wilson. Louisville: Westminster/John Knox Press.

- 1994. Syrian Christianity and Judaism, in Lieu, J, North, J \& Rajak, T (eds), The Jews among Pagans and Christians in the Roman Empire. New York: Routledge.

- 1996. Early Syriac Christianity: Some recent publications. Vigiliae Christianae 50, 159-177.

Ehlers, B 1970. Kann das Thomasevangelium aus Edessa stammen? Novum Testamentum 12, 284-317.

Elliott, J K 1993. The Apocryphal New Testament: A collection of Apocryphal Christian literature in an English translation based on $M R$ James. Oxford: Clarendon.

Fallon, F T \& Cameron, R 1988. The Gospel of Thomas: A Forschungsbericht and analysis, in Haase, W (ed), Aufstieg und Niedergang der Römerischen Welt (ANRW), 25.6, 4196-4251. Berlin: De Gruyter.

Fieger, M 1991. Das Thomasevangelium: Einleitung, Kommentar und Systematik. Münster: Aschendorff.

Gärtner, B. 1961. The theology of the Gospel according to Thomas. New York: Harper. Haenchen, E 1961. Die Botschaft der Thomas-Evangeliums. Berlin: Töpelmann.

- 1962. Spruch 68 zum Thomasevangeliums. Le Muséon 75, 19-29.

- 1973. Die Anthropologie des Thomas-Evangeliums, in Betz, H D \& Schottroff, L (eds), Neues Testament und Christliche Existenz: Festschrift für Herbert Braun, 207-227. Tübingen: J C B Mohr (Paul Siebeck).

Hartin, P J 1997. The poor in the Epistle of James and the Gospel of Thomas. HTS 53 (1\&2), 1-17.

Klijn, A F J 1960. The so-called Hymn of the Pearl (Acts of Thomas ch 108-113). Vigiliae Christianae 14, 154-164. 
Klijn, A F J 1961. Das Thomasevangelium und das altsyrische Christentum. Vigiliae Christianae 15, 146-159.

- 1962. The "Single One" in the Gospel of Thomas. JBL 81, 271-278.

- 1965. Edessa, Die Stadt des Apostels Thomas: Das älteste Christentum in Syrien. Neukirchen-Vluyn: Neukirchener Verlag des Erziehungsvereins.

- 1972. Christianity in Edessa and the Gospel of Thomas. Novum Testamentum 4, 7080.

Kloppenborg, J S 1986. Blessing and marginality: The "Persecution Beatitude" in Q, Thomas and Early Christianity. Forum 2, 3, 36-56.

Kloppenborg, J S, Meyer, M W, Patterson, S J, \& Steinhauser, M G (eds) 1990 . $Q$ Thomas Reader. Sonoma: Polebridge.

Layton, B 1987. The Gnostic Scriptures: A new translation with annotations and introduction. Garden City: Doubleday.

Lincoln, B 1977. Thomas-Gospel and Thomas-Community: A new approach to a familiar text. Novum Testamentum 19, 65-76.

Marjanaen, A 1994. Cosmos in the Gospel of Thomas, paper presented to the Thomas Consultation of the Society of Biblical Literature, 1-20.

Ménard, J-E 1968. Le Milieu Syriaque de l'Éavangile selon Thomas et de l'Éavangile selon Philippe. Revue des sciences religieuses 42, 261-266.

McGinn, B \& Meyendorf, J (eds) 1985. Christian spirituality: Origins to the twelfth century. New York: Crossroad.

Meyer, M 1992. The Gospel of Thomas. San Francisco: Harper.

Neller, KV 1989-90. Diversity in the Gospel of Thomas: Clues for a new direction. The Second Century 7, 1-38.

Patterson, S J 1993. The Gospel of Thomas and Jesus. Sonoma: Polebridge.

Turner, J D 1975. The Book of Thomas the Contender from Codex II of the Cairo Gnostic Library from Nag Hammadi (CG II, 7): The Coptic Text with translation, introduction and commentary. Missoula: Scholars.

Tuckett, C 1988. Thomas and the Synoptics. Novum Testamentum 30, 132-157.

Webster's College Dictionary. 1991. New York: Random House.

Wilkinson, J 1981. Egreria's travels to the Holy Land. rev ed Jerusalem: Ariel Publishing House, 1981. 